\title{
The clinical use of biomarkers as prognostic factors in Ewing sarcoma
}

\author{
Annmeik M van Maldegem ${ }^{1}$, Pancras CW Hogendoorn ${ }^{3}$ and Andrew B Hassan ${ }^{1,2^{*}}$
}

\begin{abstract}
Ewing Sarcoma is the second most common primary bone sarcoma with 900 new diagnoses per year in Europe (EU27). It has a poor survival rate in the face of metastatic disease, with no more than 10\% survival of the $35 \%$ who develop recurrence. Despite the remaining majority having localised disease, approximately 30\% still relapse and die despite salvage therapies. Prognostic factors may identify patients at higher risk that might require differential therapeutic interventions. Aside from phenotypic features, quantitative biomarkers based on biological measurements may help identify tumours that are more aggressive. We audited the research which has been done to identify prognostic biomarkers for Ewing sarcoma in the past 15 years. We identified 86 articles were identified using defined search criteria. A total of 11,625 patients were reported, although this number reflects reanalysis of several cohorts. For phenotypic markers, independent reports suggest that tumour size $>8 \mathrm{~cm}$ and the presence of metastasis appeared strong predictors of negative outcome. Good histological response (necrosis > 90\%) after treatment appeared a significant predictor for a positive outcome. However, data proposing biological biomarkers for practical clinical use remain un-validated with only one secondary report published. Our recommendation is that we can stratify patients according to their stage and using the phenotypic features of metastases, tumour size and histological response. For biological biomarkers, we suggest a number of validating studies including markers for 9p21 locus, heat shock proteins, telomerase related markers, interleukins, tumour necrosis factors, VEGF pathway, lymphocyte count, and a number of other markers including Ki-67.
\end{abstract}

Keywords: Ewing sarcoma, prognostic, biomarkers

\section{Introduction}

Ewing sarcoma is the second most common primary bone sarcoma. It is an orphan state disease with approximately 900 new diagnoses a year in Europe [1]. It is also called the Ewing Sarcoma Family of Tumours (ESFT) and includes Ewing sarcoma of bone, extra-osseous Ewing sarcoma, Primitive Neuroectodermal (PNET) and Askin's tumours. Ewing sarcoma is diagnostically defined by a Ewing sarcoma EWS (chromosome 22) translocation resulting in fusion with an ETS transcription factor, the commonest abnormality (85\%) being EWS-FLI1 (chromosome 11). Ewing sarcoma is a disease affecting children and young adults with a peak incidence at age fifteen. With current treatment options the 5 year survival for non-metastatic disease is $60-70 \%$. However, survival for the $25 \%$ of patients that present

\footnotetext{
* Correspondence: bass.hassan@path.ox.ac.uk

'Department of Oncology University of Oxford, Oxford, OX3 7LJ, UK

Full list of author information is available at the end of the article
}

with metastatic disease is approximately $20 \%$ [2], and for those who develop relapsed and/or refractory disease, the survival is no more than $10 \%$.

Current patients are subdivided by disease stage, namely non-metastatic, metastatic and recurrence, and patients in each group are treated the same. But apparently this subdivision is not always related to clinical outcome, because of the patients who present with nonmetastatic disease, approximately $30 \%$ die within 5 years. This group may be currently undertreated while the $70 \%$ who survive may be over-treated. It may therefore be important to separate the high risk patients from the low risk patients and to be able to detect chemotherapy resistance and metastases early.

A way of predicting patients' outcome is by using prognostic factors. The most commonly used are clinical features, eg age, gender, metastases. Biomarker is a synonym for biological markers and is defined as "a characteristic that is objectively measured and evaluated

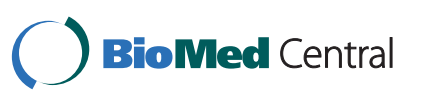

(c) 2012 van Maldegem et al; licensee BioMed Central Ltd. This is an Open Access article distributed under the terms of the Creative Commons Attribution License (http://creativecommons.org/licenses/by/2.0), which permits unrestricted use, distribution, and reproduction in any medium, provided the original work is properly cited. 
as an indicator of normal biological processes, pathogenic processor or pharmacologic responses to a therapeutic intervention" [3]. Biomarkers are currently already being used for screening, diagnosis, prognosis and monitoring of cancer patients. In 2005 the Reporting recommendations for tumour MARKer prognostic studies (REMARK) guidelines were published [4]. The goal of these guidelines is to make the results from clinical prognostic studies transparent and to improve the level of comparison that is possible between studies.

We report an overview of the research which has been done to identify reliable biomarkers for Ewing sarcoma in the past 15 years, where we detail the kind of markers that have been tested, the number of patients involved and the p-value showing the significance of the marker. The results highlight some interesting biomarkers, but they have yet to be validated.

\section{Materials and methods}

\section{Search strategy}

We report data available in the public domain only. Papers were identified from PubMed searches and from references in the found articles. The search algorithm was: (Ewing sarcoma) AND (prognostic factors) OR (biomarker). Only papers published between 1995 and 2010 are included. The latest search was done in June 2010. Whenever multiple reports from the same study were published, we used only the report with the latest published date to avoid any duplication of information. Papers were eligible if they: (1) described (or cited a paper that described) a Ewing sarcoma study of prognostic factors or biomarkers; (2) were published in English; and (3) came from industrialized countries. All types of evaluation were accepted (full papers, conference abstracts, reports) as long as results (including data) were presented.

\section{Data extraction}

Data extraction was conducted independently by the first author (A.M. v. M.). We used a systematic method for the search normally used for meta-analysis [5]. Differences in data extraction were resolved by consensus with a second author (A.B.H). From each eligible trial we recorded authors' names, journal and year of publication and the results from the study.

\section{Results and Discussion Eligible trials}

A flow-chart indicating the identification of reports for inclusion in the analysis is reported for Ewing sarcoma (Figure 1). During the search many reports had to be excluded mainly because no prognostic markers were reported in the article. When we searched the reports using full text, we had to exclude some papers because no Ewing sarcoma patients were included in these

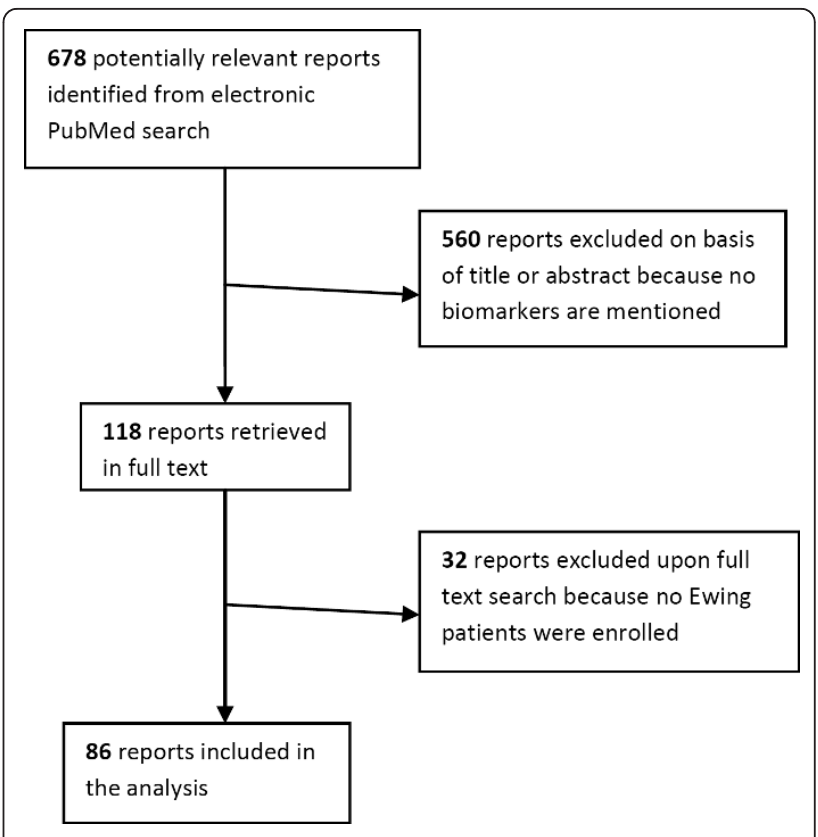

Figure 1 Flowchart for the identification of eligible reports.

reports. We identified 86 articles which were eligible for our search criteria. In these papers a total of 11,625 patients were reported.

In this report we looked at the published data on the use of biomarkers for the last 15 years. Biomarkers were grouped into phenotypic markers and biological markers. Markers were taken as statistically significant if $\mathrm{p}<$ 0.05 . For phenotypic markers we reported the outcome for gender, tumour size, presence of metastases and histological response after treatment (Tables 1, 2, 3 \&4). We showed the p-value reported in the eligible articles and the distribution of $\mathrm{p}$ correlated to the number of patients (Figures 2). There doesn't seem to be a relationship between the number of patients and the p-value. For example, the distribution of histological response shows that the studies with small patient numbers have the same statistical significance as these with large patient numbers. Throughout this report, the assumption is that the biomarker has a linear relationship to outcome. We know that for many biomarkers, this is not the case. For example, data transformation using either bicubic splines or fractional polynomials is often required to correlate continuous relationships between biomarkers and outcome, as opposed to predefined cutpoints [6]. We can only have limited extrapolation of the reported data to outcome as in most instances these questions have not been addressed.

\section{Primary outcome}

The investigated biomarkers are subdivided in two groups, phenotypic markers and biological markers. For 
Table 1 Outcome for phenotypic marker: gender

\begin{tabular}{lccc}
\hline Author & Year & $\begin{array}{c}\text { Pt } \\
\text { number }\end{array}$ & P \\
\hline Craft et al, Eur J Cancer 33 (7), 1061-9[8] & 1997 & 142 & 0.3 \\
\hline Aparicio et al, Oncology 55, 20-6 [9] & 1998 & 116 & NS \\
\hline Ahrens et al, Med Pediatr Oncol 32, 186-95 [10] & 1999 & 177 & 0.92 \\
\hline Ginsberg et al, J Clin Oncol 17, 1809-14[11] & 1999 & 85 & 0.79 \\
\hline Givens et al, Int J Oncol 14 (6), 1039-43[12] & 1999 & 85 & NS \\
\hline Bacci et al, J Clin Oncol 18, 4-11[13] & 2000 & 359 & 0.02 \\
\hline Jenkin et al, Med Pediatr Oncol 37, 383-9[14] & 2001 & 93 & 0.73 \\
\hline Krasin et al, Cancer 104, 367-73[15] & 2005 & 33 & 0.25 \\
\hline Bacci et al, Acta Oncol 45, 469-75[16] & 2006 & 579 & 0.03 \\
\hline De Angulo et al, J Pediatr Hematol Oncol 29 & 2007 & 24 & NS \\
(1), 48-52[17] & & & \\
\hline Leavey et al, Pediatr Blood Cancer 51 (3), 334-8 & 2008 & 262 & 0.05 \\
\hline [18] & & & \\
\hline Jawad et al, Cancer 115, 3526-36[19] & 2009 & 1631 & 0.004 \\
\hline Kikuta et al, Clin Cancer Res 15 (8), 2885-94[20] & 2009 & 8 & 0.53 \\
\hline Sari et al, Pediatr Blood Cancer 54, 19-24[21] & 2010 & 87 & 0.04 \\
\hline Xie et al, Chin J Cancer 29 (4), 420-4 & 2010 & 18 & 0.36 \\
\hline NS: not significant & & &
\end{tabular}

the phenotypic markers gender, tumour size, metastases and histological response are reported in Tables 1, 2, 3 and 4 . For all these phenotypic markers we compared the patient number and $\mathrm{p}$-value, in which $\mathrm{p}<0.05$ was taken as statistically significant. However we weren't able to retrieve the p-value in all articles, sometimes it was only mentioned as being significant or non-significant. For each phenotypic marker we looked at the differences in overall survival between: for gender, men vs women; for tumour size, $<8-10 \mathrm{~cm}$ vs $>8-10 \mathrm{~cm}$; for metastasis presence at initial presentation vs absence and for histological response, $>90 \%$ necrosis vs $<90 \%$ necrosis. Distributions of $\mathrm{p}$ related to patient numbers in these four phenotypic markers are shown in Figures 2. For these four phenotypic markers we show that there is no correlation between the number of patients and the statistical significance of the outcome. More phenotypic markers were reported: fusion type, ethnicity, performance status and margins. However because of the low number of studies which reported these outcomes these results are not shown in detail. In 26 articles the impact of tumour site on the overall survival is shown, but because sites are compared in different ways it is difficult to summarize these findings.

Currently clinical stage is being used to determine whether a patient has a high or low risk for developing metastases or recurrence. However, it seems that clinical stage is not always related to outcome, because of the patients who present with non-metastatic disease, only $70 \%$ of them survive for 5 -years. Therefore, what is the difference between the $70 \%$ of the patients who
Table 2 Outcome for phenotypic marker: tumour size

\begin{tabular}{|c|c|c|c|}
\hline Author & Year & $\begin{array}{c}\mathrm{Pt} \\
\text { number }\end{array}$ & $P$ \\
\hline Aparicio et al, Oncology 55, 20-6[9] & 1998 & 116 & 0.0016 \\
\hline Kawai et al, Cancer 82, 851-9[22] & 1998 & 20 & 0.0038 \\
\hline Ahmad et al, Cancer 85, 725-31[23] & 1999 & 24 & 0.277 \\
\hline Givens et al Int J Oncol 14 (6), 1039-43[12] & 1999 & 85 & NS \\
\hline Cotterill et al, J Clin Oncol 18, 3108-14[24] & 2000 & 975 & 0.001 \\
\hline De Alava et al, Cancer 89, 783-92[25] & 2000 & 55 & 0.02 \\
\hline Jenkin et al, Med Pediatr Oncol 37, 383-9[14] & 2001 & 93 & 0.0001 \\
\hline Oberlin et al, B J Cancer 85 (11), 1646-54[26] & 2001 & 141 & 0.002 \\
\hline i et al, J Surg Oncol 84, 151-9[27] & 2003 & 13 & 0.05 \\
\hline $\begin{array}{l}\text { Krasin et al, Pediatr Blood Cancer 43, 229-36 } \\
{[28]}\end{array}$ & 2004 & 37 & $S$ \\
\hline $\begin{array}{l}\text { Matsunobu et al, Clin Cancer Res 10, 1003-12 } \\
\text { [29] }\end{array}$ & 2004 & 21 & 0.05 \\
\hline Krasin et al, Cancer 104, 367-73[28] & 2005 & 33 & 0.25 \\
\hline Aksnes et al, Acta Oncol 45, 38-46[30] & 2006 & 56 & 0.001 \\
\hline Bacci et al, Acta Oncol 45, 469-75[16] & 2006 & 579 & 0.0004 \\
\hline Mikulic et al, J Pediatr Surg 41, 524-9[31] & 2006 & 27 & 0.031 \\
\hline $\begin{array}{l}\text { Cheung et al, Clin Cancer Res } 13 \text { (23), 6978-83 } \\
\text { [32] }\end{array}$ & 2007 & 28 & NS \\
\hline $\begin{array}{l}\text { Rodriguez-Galindo et al, Ann Oncol 19, 814-20 } \\
\text { [33] }\end{array}$ & 2008 & 220 & 0.018 \\
\hline $\begin{array}{l}\text { Yonemori et al, J Cancer Res Clin Oncol 134, } \\
\text { 389-95[34] }\end{array}$ & 2008 & 79 & S \\
\hline Jawad et al, Cancer 115, 3526-36[19] & 2009 & 1631 & 0.001 \\
\hline $\begin{array}{l}\text { Kikuta et al, Clin Cancer Res } 15 \text { (8), 2885-94 } \\
\text { [20] }\end{array}$ & 2009 & 8 & 0.018 \\
\hline Lee et al, Cancer 116, 1964-73[35] & 2010 & 725 & 0.001 \\
\hline Xie et al, Chin J Cancer 29 (4), 420-4 & 2010 & 18 & 0.44 \\
\hline
\end{tabular}

NS: not significant, S: significant

survive and the $30 \%$ who don't? Can one somehow foretell chemotherapy resistance and detect metastases early? One way to predict the outcome of patients apart from clinical stage is to use biomarkers. These are objective measurements which reflect biological processes. The biomarkers currently being used are tumour size and the presence of metastases. Biological markers are not being used, even though they may provide a way to predict a patient's outcome more accurately than phenotypic markers. From the results for phenotypic markers we can see that gender is probably not significant important for patient outcome. In 15 articles we found 11 reports that gender is nonsignificant. Tumour size $>8 \mathrm{~cm}$ seems to be important, with 15 out of 22 articles finding it to be a predictor and significantly related to negative outcome. The presence of metastasis is a strong predictor of negative outcome with 24 articles reporting it as significantly relevant compared to only 3 reporting it as non-significant. For histological response, 12 out of 16 
Table 3 Outcome for phenotypic marker: metastases

\begin{tabular}{|c|c|c|c|}
\hline Author & Year & $\begin{array}{c}\mathrm{Pt} \\
\text { number }\end{array}$ & $P$ \\
\hline Terrier et al, Eur J Cancer 31 (3), 307-14[36] & 1995 & 315 & 0.003 \\
\hline $\begin{array}{l}\text { Terrier et al, Semin Diagn Pathol } 13 \text { (3), 250-7 } \\
\text { [37] }\end{array}$ & 1996 & 315 & $\mathrm{~S}$ \\
\hline Aparicio et al, Oncology 55, 20-6[9] & 1998 & 116 & 0.03 \\
\hline De Alava et al, J Clin Oncol 16 (4), 1248-55[38] & 1998 & 99 & 0.008 \\
\hline $\begin{array}{l}\text { Paulussen et al, J Clin oncol } 16 \text { 99), 3044-52 } \\
\text { [39] }\end{array}$ & 1998 & 114 & $S$ \\
\hline [23] & 1999 & 24 & 0.219 \\
\hline Baldini et al, Ann Surg 230 (1), 79-86[40] & 1999 & 37 & 0.002 \\
\hline Ginsberg et al, J Clin Oncol 17, 1809-14[11] & 1999 & 85 & 0.33 \\
\hline Luksch et al, Tumori 85 (2), 101-7[41] & 1999 & 73 & $\mathrm{~S}$ \\
\hline Cotterill et al, J Clin Oncol 18, 3108-14[24] & 2000 & 975 & 0.0001 \\
\hline De Alava e & 2000 & 55 & 0.02 \\
\hline Wei et al, Cancer 89, 793-9[42] & 2000 & 39 & 0.001 \\
\hline Jenkin et al, Med Pediatr Oncol 37, 383-9[14] & 2001 & 93 & 0.04 \\
\hline Zielenska et al, Cancer 91, 2156-64[43] & 2001 & 26 & 0.0137 \\
\hline Martin et al, Arch Surg 138, 281-5[44] & 2003 & 59 & 0.02 \\
\hline Fuchs et al, Clin Cancer Res 10, 1344-53[45] & 2004 & 31 & 0.022 \\
\hline $\begin{array}{l}\text { Matsunobu et al, Clin Cancer Res 10, 1003-12 } \\
\text { [29] }\end{array}$ & 2004 & 21 & NS \\
\hline Weston et al, B J Cancer 91, 225-32[46] & 2004 & 385 & 0.001 \\
\hline Aksnes et al, Acta Oncol 45, 38-46[30] & 2006 & 56 & 0.001 \\
\hline Kreuter, Eur J Cancer 45, 1904-11[47] & 2006 & 40 & 3 \\
\hline $\begin{array}{l}\text { La et al, Int J Radiat Oncol Biol Phys } 64 \text { (2), } \\
544-50[48]\end{array}$ & 2006 & 60 & 0.036 \\
\hline $\begin{array}{l}\text { Cheung et al, Clin Cancer Res } 13 \text { (23), 6978-83 } \\
\text { [32] }\end{array}$ & 2007 & 28 & 0.04 \\
\hline $\begin{array}{l}\text { Leavey et al, Pediatr blood Cancer } 51 \text { (3), 334- } \\
8[18]\end{array}$ & 2008 & 262 & 0.02 \\
\hline $\begin{array}{l}\text { Yonemori et al, J Cancer Res Clin Oncol 134, } \\
\text { 389-95[34] }\end{array}$ & 2008 & 79 & 0.02 \\
\hline Jawad et al, Cancer 115, 3526-36[19] & 2009 & 385 & 0.001 \\
\hline Sari et al, Pediatr Blood Cancer 54, 19-24[21] & 2010 & 87 & 0.001 \\
\hline Xie et al, Chin J Cancer 29 (4), 420-4 & 2010 & 18 & 0.01 \\
\hline
\end{tabular}

NS: not significant, S: significant

articles found that necrosis $>90 \%$ after treatment is a significant predictor for positive outcome.

For some phenotypic markers it is unclear how the cut-off point between predictor of positive or negative outcomes is determined. For tumour size the cut-off point for negative outcome is $>8 \mathrm{~cm}$, but it is undefined how this is selected. It seems more logical that tumour size is a continuous variable with an increasingly negative outcome with increasing size. The same can probably be said for age and surgical margins.

Biological markers are more difficult to compare, because for most of these markers only one or two reports are published. We grouped the biological markers according to their function and we ended up with
Table 4 Outcome for phenotypic marker: histological response

\begin{tabular}{|c|c|c|c|}
\hline Author & Year & $\begin{array}{c}\mathrm{Pt} \\
\text { number }\end{array}$ & $\mathbf{P}$ \\
\hline Delepine et al, J Chemother 9 (5), 352-63[49] & 1997 & 39 & 0.05 \\
\hline Picci et al, J Clin Oncol 15 (4), 1553-9[50] & 1997 & 118 & 0.0001 \\
\hline Aparicio et al, Oncology 55, 20-6[9] & 1998 & 116 & 0.018 \\
\hline $\begin{array}{l}\text { Paulussen et al, J Clin Oncol } 16 \text { (9), 3044-52 } \\
\text { [39] }\end{array}$ & 1998 & 114 & S \\
\hline $\begin{array}{l}\text { Abudu et al, J Bone Joint Surg } 81 \text { (2), 317-22 } \\
\text { [51] }\end{array}$ & 1999 & 50 & 0.03 \\
\hline $\begin{array}{l}\text { Ahrens et al, Med Pediatr Oncol 32, 186-95 } \\
{[10]}\end{array}$ & 1999 & 177 & 0.27 \\
\hline Baldini et al, Ann Surg 230 (1), 79-86[40] & 1999 & 37 & 0.01 \\
\hline Bacci et al, J Clin Oncol 18, 4-11[13] & 2000 & 359 & 0.001 \\
\hline De Alava et al, Cancer 89, 783-92[25] & 2000 & 55 & 0.001 \\
\hline Ohali et al, J Clin Oncol 21, 3836-43[52] & 2003 & 31 & 0.0001 \\
\hline Scotlandi et al, Eur J Cancer 41, 1349-61[53] & 2005 & 113 & 0.05 \\
\hline Bacci et al, Acta Oncol 45, 469-75[16] & 2006 & 579 & 0.0005 \\
\hline Mikulic et al, J Pediatr Surg 41, 524-9[31] & 2006 & 27 & 0.047 \\
\hline $\begin{array}{l}\text { Avigad et al, Clin Cancer Res } 13 \text { (19), 5777-83 } \\
\text { [54] }\end{array}$ & 2007 & 32 & 0.13 \\
\hline $\begin{array}{l}\text { Yonemori, J Cancer Res Clin Oncol 134, 389- } \\
95 \text { v [34] }\end{array}$ & 2008 & 79 & 0.04 \\
\hline Meynet et al, Cancer Res 70 (9), 3730-8[55] & 2010 & 97 & 0.02 \\
\hline
\end{tabular}

5 groups, namely cell cycle, karyotype, immunological, blood products and the remaining biological markers which couldn't be classified in one of the other groups. The results from the biological markers are shown in Tables 5, 6, 7, 8 and 9. The correlation between patient number and statistical significance of the outcome for the five groups is shown in Figures 3. We show that there is no correlation between the patient number and the statistical significance of the outcome. It appears

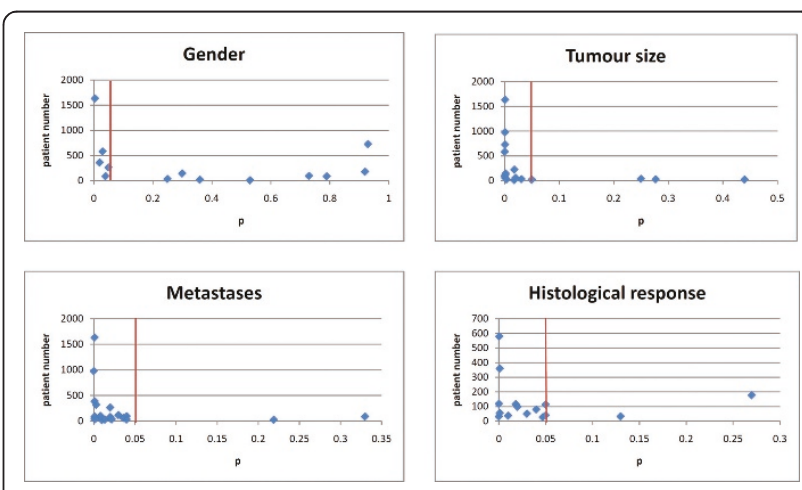

Figure 2 Distribution of $p$ related to patient number for the phenotypic markers: gender, tumour size, metastases and histological response. The red line shows the cut-off point of $p=$ 0.05 . 
Table 5 Outcome for biological markers: cell cycle

\begin{tabular}{|c|c|c|c|c|}
\hline Author & Year & Biomarker & Pt number & $P$ \\
\hline Landanyi et al, J Pathol 175 (2), 211-7 & 1995 & $\mathrm{MDM}-2$ & 30 & 0.005 \\
\hline Luksch et al, Tumori 85 (2), 101-7[41] & 1999 & Mitose presence & 73 & $\mathrm{~S}$ \\
\hline Sollazzo et al, tumori 85 (3), 167-73[56] & 1999 & Ki-67 & 38 & 0.01 \\
\hline De Alava et al, Cancer 89, 783-92[25] & 2000 & Ki-67 & 55 & 0.005 \\
\hline Abudu et al, Br J Cancer 79(7-8), 1185-9[57] & 1999 & P53 & 50 & 0.02 \\
\hline Huang et al, J Clin Oncol 23, 548-58[58] & 2005 & P53 & 60 & 0.001 \\
\hline Matsunobu et al, C;in Cancer Res 10, 1003-12[29] & 2004 & P27 & 21 & 0.01 \\
\hline Wei et al, Cancer 89, 793-9[42] & 2000 & INK4a & 39 & 0.001 \\
\hline Maitra et al, Arch Pathol Lab Med 125, 1207-12[59] & 2001 & P16INK4a & 20 & 0.41 \\
\hline Maitra et al, Arch Pathol Lab Med 125, 1207-12[59] & 2001 & P14ARF & 20 & NS \\
\hline Huang et al, J Clin Oncol 23, 548-58[58] & 2005 & P16/p14ARF & 60 & 0.03 \\
\hline Maitra et al, Arch Pathol Lab Med 125, 1207-12[59] & 2001 & P21WAF1 & 20 & 0.61 \\
\hline Ohali et al, Oncogene 23, 8997-9006[60] & 2004 & Cadherin-11 & 20 & 0.024 \\
\hline Cheung et al, Clin Cancer Res 13 (23), 6978-83[32] & 2007 & STEAP1 & 28 & 0.0012 \\
\hline Cheung et al, Clin Cancer Res 13 (23), 6978-83[32] & 2007 & CCND1 & 28 & 0.0077 \\
\hline Martins et al, Cancer Res 68 (15), 6260-70[61] & 2008 & Heat shock 90 & 54 & S \\
\hline Zanini et al, Virchows Arch 452, 157-67[62] & 2008 & Heat shock 27 & unknown & NS \\
\hline
\end{tabular}

S: significant, NS: not significant

Table 6 Outcome for biological markers: karyotype

\begin{tabular}{|c|c|c|c|c|}
\hline Author & Year & Biomarker & Pt number & $\mathbf{P}$ \\
\hline Tarkannen et al, Cancer Genet Cytogenet 114, 35-41 & 1999 & $1 q$ & 28 & NS \\
\hline Hattinger et al, Br J Cancer 86, 1763-9[63] & 2002 & $1 q$ & 134 & 0.046 \\
\hline Tarkannen et al, Cancer Genet Cytogenet 114, 35-41 & 1999 & $6 \mathrm{p} 2.1$ & 28 & 0.004 \\
\hline Lopez-Guerrero et al, Lab Invest 81 (6), 803-14[64] & 2001 & 9p21 locus & 19 & 0.005 \\
\hline Hattinger et al, Br J Cancer 86, 1763-9[63] & 2002 & $16 q$ & 134 & 0.008 \\
\hline Hattinger et al, Genes Chromosomes Cancer 24 (3), 243-54[65] & 1999 & Chr 1 & 58 & 0.004 \\
\hline Tarkannen et al, Cancer Genet Cytogenet 114, 35-41 & 1999 & Chr 8 & 28 & NS \\
\hline Hattinger et al, Genes Chromosomes Cancer 24 (3), 243-54[65] & 1999 & Chr 8 & 58 & 0.17 \\
\hline Hattinger et al, Br J Cancer 86, 1763-9[63] & 2002 & Chr 8 & 134 & NS \\
\hline Tarkannen et al, Cancer Genet Cytogenet 114, 35-41 & 1999 & Chr 12 & 28 & NS \\
\hline Hattinger et al, Genes Chromosomes Cancer 24 (3), 243-54 [65] & 1999 & Chr 12 & 58 & 0.63 \\
\hline Hattinger et al, Br J Cancer 86, 1763-9[63] & 2002 & Chr 12 & 134 & 0.009 \\
\hline Ohali et al, J Clin Oncol 21, 3836-43[52] & 2003 & Telomerase activity & 31 & 0.0001 \\
\hline Avigad et al, Clin Cancer Res 13 (19), 5777-83[54] & 2007 & Telomerase length & 32 & 0.015 \\
\hline
\end{tabular}

NS: not significant, Chr: Chromosome

Table 7 Outcome for biological markers: immunological

\begin{tabular}{lllll}
\hline Author & Year & Biomarker & Pt number & P \\
\hline Rutkowski et al, J Surg Oncol 84, 151-9[27] & 2003 & IL-1ra & 13 & 13 \\
\hline Rutkowski et al, J Surg Oncol 84, 151-9[27] & 2003 & IL-2ra & 13 & 0.0001 \\
\hline Rutkowski et al, J Surg Oncol 84, 151-9[27] & 2003 & IL-6 & 13 & 0.005 \\
\hline Rutkowski et al, J Surg Oncol 84, 151-9[27] & 2003 & IL-8 & 13 & 0.001 \\
\hline Rutkowski et al, J Surg Oncol 84, 151-9[27] & 2003 & IL-10 & 13 & 0.001 \\
\hline Rutkowski et al, J Surg Oncol 84, 151-9[27] & 2003 & TNF RI & 13 & 0.001 \\
\hline Rutkowski et al, J Surg Oncol 84, 151-9[27] & 2003 & TNF RII & 13 & 0.01 \\
\hline Rutkowski et al, J Surg Oncol 84, 151-9[27] & 2003 & M-CSF & 67 & 0.01 \\
\hline Berghuis et al, J Pathol 218, 222-31[66] & 2009 & HLA class I & NS \\
\hline
\end{tabular}


Table 8 Outcome for biological markers: blood products

\begin{tabular}{|c|c|c|c|c|}
\hline Author & Year & Biomarker & Pt number & $\mathbf{P}$ \\
\hline Holzer et al, Med Pediatr Oncol 36 (6), 601-4[67] & 2001 & VEGF & 6 & NS \\
\hline Pavlakovic et al, Int J Cancer 92, 756-60 [68] & 2001 & VEGF & 4 & 0.017 \\
\hline Rutkowski et al, J Surg Oncol 84, 151-9[27] & 2003 & VEGF & 13 & NS \\
\hline Fuchs et al, Clin Cancer Res 10, 1344-53[45] & 2004 & VEGF & 31 & 0.0047 \\
\hline Jimeno et al, Pediatr Blood Cancer 49, 352-7[69] & 2007 & VEGF & 16 & NS \\
\hline Kreuter et al, Eur J Cancer 42, 1904-11[47] & 2006 & VEGF-A & 40 & 0.013 \\
\hline Kreuter et al, Eur J Cancer 42, 1904-11[47] & 2006 & VEGFR-1 & 40 & 0.946 \\
\hline Kreuter et al, Eur J Cancer 42, 1904-11[47] & 2006 & VEGFR-2 & 40 & 0.946 \\
\hline Aparicio et al, Oncology 55, 20-6[9] & 1998 & Lymphocyte count & 116 & 0.0044 \\
\hline De Angulo et al, J Pediatr Hematol Oncol 29 (1), 48-52[17] & 2007 & Lymphocyte count & 24 & 0.001 \\
\hline De Angulo et al, J Pediatr Hematol Oncol 29 (1), 48-52 [17] & 2007 & Platelet count & 24 & NS \\
\hline De Angulo et al, J Pediatr Hematol Oncol 29 (1), 48-52[17] & 2007 & Neutrophil count & 24 & NS \\
\hline Aparicio et al, Oncology 55, 20-6[9] & 1998 & Erythrocyte sedimentation rate & 116 & 0.02 \\
\hline Oberlin et al, B J Cancer 85 (11), 1646-54[26] & 2001 & Erythrocyte sedimentation rate & 141 & 0.04 \\
\hline Yabe et al, Oncol Rep 19 (1), 129-34[70] & 2008 & Erythrocyte sedimentation rate & 20 & NS \\
\hline
\end{tabular}

NS: not significant

that ki67, an S-phase cell cycle biomarker, may be a biomarker of cell activity in the tumour that significantly correlates with outcome. The mechanism for the activation of cell cycle appears unclear, but is presumably driven by other factors other that EWS-FLI1 translocation. Loss of function of cell cycle dependent kinases (p16, p14, p21) and other regulators of the cell cycle through the p53 pathway (MDM2, p53), also appear deregulate in a proportion of tumours and potentially are useful prognostic markers. Importantly, activity of telomerase appears significantly correlated with outcome as occurs in many other tumours. There appears much interest in

Table 9 Outcome for biological markers: remaining

\begin{tabular}{|c|c|c|c|c|}
\hline Author & Year & Biomarker & Pt number & $\mathbf{P}$ \\
\hline Craft et al, Eur J Cancer 33 (7), 1061-9[8] & 1997 & $\mathrm{LDH}$ & 142 & NS \\
\hline Aparicio et al, Oncology 55, 20-6[9] & 1998 & $\mathrm{LDH}$ & 116 & 0.001 \\
\hline Givens et al, Int J Oncol 14 (6), 1039-43[12] & 1999 & $\mathrm{LDH}$ & 85 & NS \\
\hline Bacci et al, Oncol Rep 6 (4), 807-11[71] & 1999 & $\mathrm{LDH}$ & 618 & $S$ \\
\hline Luksch et al, Tumori 85 (2), 101-7[41] & 1999 & $\mathrm{LDH}$ & 73 & S \\
\hline Bacci et al, J Clin Oncol 18, 4-11[13] & 2000 & $\mathrm{LDH}$ & 359 & 0.0003 \\
\hline Matsunobu et al, Clin Cancer Res 10, 1003-12[29] & 2004 & $\mathrm{LDH}$ & 21 & NS \\
\hline Bacci et al, Acta Oncol 45, 469-75[16] & 2006 & $\mathrm{LDH}$ & 579 & 0.0005 \\
\hline Cheung et al, Clin Cancer Res 13 (23), 6978-83[32] & 2007 & $\mathrm{LDH}$ & 28 & 0.99 \\
\hline Yabe et al, Oncol Rep 19 (1), 129-34[70] & 2008 & $\mathrm{LDH}$ & 20 & NS \\
\hline Leavey et al, Pediatr Blood Cancer 51 (3), 334-8[18] & 2008 & $\mathrm{LDH}$ & 262 & 0.0016 \\
\hline Xie et al, Chin J Cancer 29 (4), 420-4 & 2010 & $\mathrm{LDH}$ & 18 & NS \\
\hline Terrier et al, Eur J Cancer 31 (3), 307-14[36] & 1995 & Filigree pattern & 315 & 0.044 \\
\hline Terrier et al, Eur J Cancer 31 (3), 307-14[36] & 1995 & Dark cells & 315 & 0.043 \\
\hline Aparicio et al, Oncology 55, 20-6[9] & 1998 & Albumine levels & 116 & 0.0006 \\
\hline Sollazzo et al, Tumori 85 (3), 167-73[56] & 1999 & c-myc & 38 & $S$ \\
\hline Ohali et al, Oncogene 23, 8997-9006[60] & 2004 & MTA1 & 20 & 0.003 \\
\hline Cheung et al, Clin Cancer Res 13 (23), 6978-83[32] & 2007 & NKX2-2 & 28 & 0.0017 \\
\hline Kikuta et al, Clin Cancer Res 15 (8), 2885-94[20] & 2009 & Nucleophosmin positivity & 8 & 0.01 \\
\hline Meynet et al, Cancer Res 70 (9), 3730-8[55] & 2010 & Xg expression & 97 & 0.047 \\
\hline
\end{tabular}

S: significant, NS: not significant 
secondary copy number changes and mutations in Ewing sarcoma, and in particular, chromosome 1 (Table 6). For example, recent evidence points to gain of $1 \mathrm{q}$ and alteration in abundance of a gene product called CDt2 involved in ubiquitination [7]. It is however difficult to objectively say anything about the other reported markers because they may influence each other. This appears most clear for tumour size and metastases, where bigger tumours may correlate with a higher chance of having metastases. For biological markers it is probably the same issue, but less clear because we don't really know their true experimental influence on tumour genesis. For example, LDH levels are probably a reflection of cell turnover in larger tumours, and may be an indirect measure of bulk of disease (comparing Table 2 versus Table 9). It is also more difficult to say anything about biological markers because they haven't been tested as extensively as phenotypic markers, and certainly they have not often been validated independently. Results for most of these markers are only reported in 1 or 2 articles with sometimes small numbers of patients and no statistical validation. To improve this situation it would important to capture high quality clinical material and clinical outcome to develop a bio-bank. We may be able to test the most promising biomarkers from previously run studies and so define their significance. Either a multivariate analysis or data mining analysis should be done to evaluate the way biomarkers affect each other. The easiest way to achieve this objective is by collecting material and outcome data from large phase III trials. It is also important to standardize the way material is collected and how the biomarkers are compared. For example, the phenotypic marker tumour site is the most often tested marker with results published in 26 articles (data not shown). However it is not possible to say anything about these results since different tumour sites are compared in the reports. This is also true for the marker age in which different age groups are compared with each other, for example some articles compare patients < 18 years vs > 18 years, others $<30$ years vs $>30$ years (data not shown).

For markers of tumour growth, angiogenesis if often quantified, but so far biomarker analysis has been predominantly limited to measurement of VEGF pathway (Table 8). The immunological biological markers interleukins and tumour necrosis factors seem very promising (Table 7). However these have all been tested in one institute, with very small patient numbers and the data doesn't seem to be validated. Most of the biological markers mentioned in the blood products group (Table 8) are probably surrogates for tumour size and they should be validated in either a multivariate analysis or
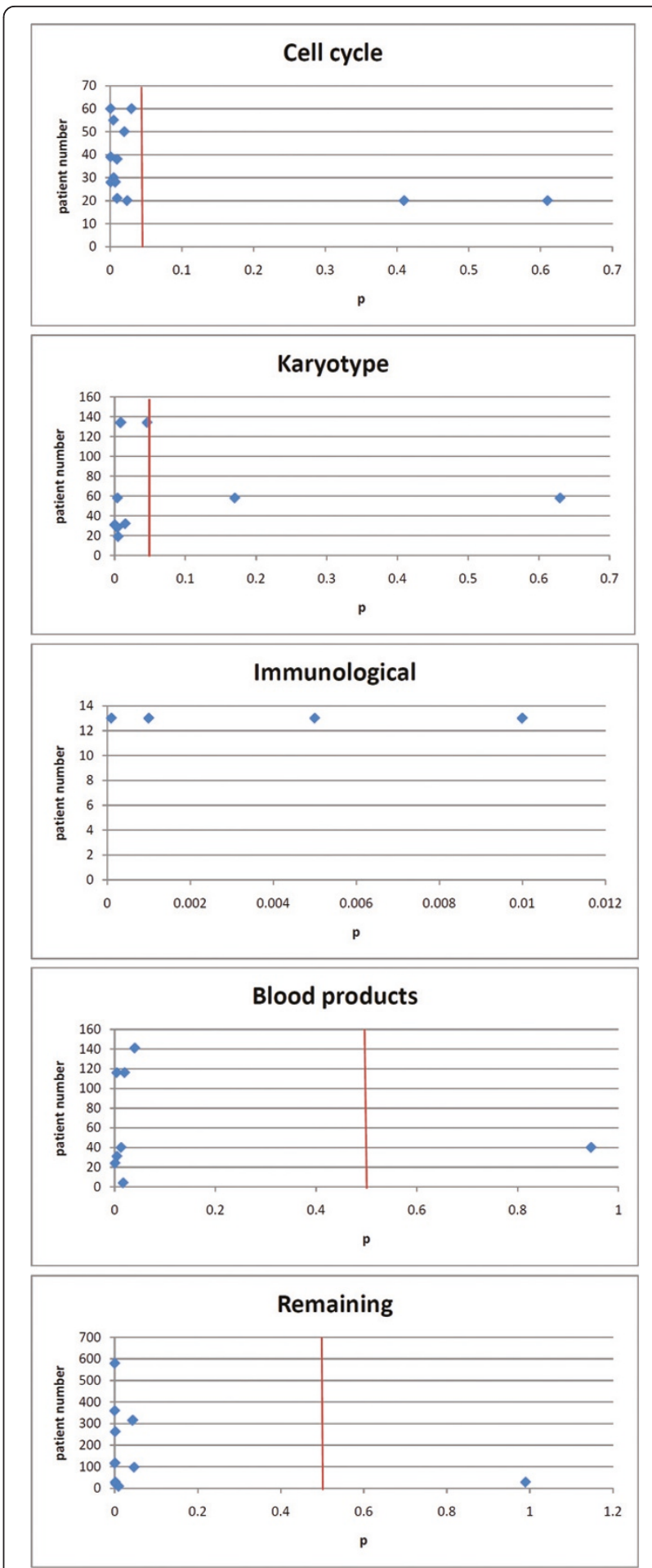

Figure 3 Distribution of $p$ related to patient number for the biological markers related to cell cycle, karyotype, immunological, blood products and remaining markers. The red line shows the cut-off point of $p=0.05$. Note, there is no line for immunological phenotypic markers because for all the results $p<$ 0.05 . 
machine learning to see if they can be used as an objective biological marker.

At the present time it is no possible to make a definite list of biological biomarkers able to predict patient outcome, mainly because these markers also have to be stratified with respect to the major staging phenotypic features, e.g. presence of metastasis and degree of histological response. It is also unclear what quality control measure were used in the limited patient cohorts. Our recommendation would be continue divide patients according to their disease stage and also to use the phenotypic biomarkers metastasis, tumour size and histological response. For biological biomarkers we would like to validate previous work done on the markers for $9 \mathrm{p} 21$ locus and the involved genes and proteins, heat shock proteins, telomerase related markers, interleukins, tumour necrosis factors, VEGF pathway, lymphocyte count, MTA1, STEAP1, CCND1, MDM-2, Ki-67, p53, p27 and cadherin-11. At this time, neither phenotypic (clinical) or biological biomarkers are utilised in stratification of patients in clinical trials.

\section{Lists of abbreviations}

LDH: Lactate dehydrogenase; REMARK: Reporting recommendations for tumour MARKer prognostic studies; ESFT: Sarcoma Family of Tumours; PNET: Primitive Neuroectodermal.

\section{Acknowledgements}

We thank EuroBoNeT FP6 ROK for funding and the Oxford Biomedical Research Centre for support.

\section{Author details \\ 'Department of Oncology University of Oxford, Oxford, OX3 7LJ, UK. ${ }^{2}$ Sir William Dunn School of Pathology, University of Oxford, Oxford, OX1 3RE, UK. ${ }^{3}$ Department of Pathology, Leiden University Medical Centre, PO Box 9600, 2600 RC Leiden, The Netherlands.}

\section{Authors' contributions}

$\mathrm{ABH}$ conceived the study, AVM collected data with $\mathrm{ABH}, \mathrm{AVM}$ and $\mathrm{ABH}$ wrote the paper and PCH made detailed comments. All authors have read and approved the final version of the manuscript.

\section{Competing interests}

All authors have no competing financial interests in the publication of this manuscript.

No organisation is funding or implicated in the manuscripts analysis and interpretation.

Academic interests of the authors are to improve the outcome of patients with sarcoma, and this publication forms part of the deliverable output from EU funding from EuroBoNeT.

Received: 25 June 2011 Accepted: 8 February 2012 Published: 8 February 2012

\section{References}

1. Gatta G, van der Zwan JM, Casali PG, Siesling S, Dei Tos AP, Kunkler I, Otter R, Licitra L, Mallone S, Tavilla A, et al: Rare cancers are not so rare: The rare cancer burden in Europe. Eur J Cancer 2011, 47:2493-2511.

2. Rodriguez-Galindo C, Navid F, Liu T, Billups CA, Rao BN, Krasin MJ: Prognostic factors for local and distant control in Ewing sarcoma family of tumors. Ann Oncol 2008, 19:814-820.

3. Biomarkers and surrogate endpoints: preferred definitions and conceptual framework. Clin Pharmacol Ther 2001, 69:89-95.
4. McShane LM, Altman DG, Sauerbrei W, Taube SE, Gion M, Clark GM: REporting recommendations for tumour MARKer prognostic studies (REMARK). Br J Cancer 2005, 93:387-391.

5. Hamada C: The role of meta-analysis in cancer clinical trials. Int J Clin Oncol 2009, 14:90-94

6. Stocken DD, Hassan AB, Altman DG, Billingham $L$, Bramhall SR, Johnson PJ, Freemantle N: Modelling prognostic factors in advanced pancreatic cancer. Br J Cancer 2008, 99:883-893.

7. Mackintosh C, Ordonez JL, Garcia-Dominguez DJ, Sevillano V, LlombartBosch A, Szuhai K, Scotlandi K, Alberghini M, Sciot R, Sinnaeve F, et al: 1q gain and CDT2 overexpression underlie an aggressive and highly proliferative form of Ewing sarcoma. Oncogene 2011.

8. Craft AW, Cotterill SJ, Bullimore JA, Pearson D: Long-term results from the first UKCCSG Ewing's Tumour Study (ET-1). United Kingdom Children's Cancer Study Group (UKCCSG) and the Medical Research Council Bone Sarcoma Working Party. Eur J Cancer 1997, 33:1061-1069.

9. Aparicio J, Munarriz B, Pastor M, Vera FJ, Castel V, Aparisi F, Montalar J, Badal MD, Gomez-Codina J, Herranz C: Long-term follow-up and prognostic factors in Ewing's sarcoma. A multivariate analysis of 116 patients from a single institution. Oncology 1998, 55:20-26.

10. Ahrens S, Hoffmann C, Jabar S, Braun-Munzinger G, Paulussen M, Dunst J, Rube C, Winkelmann W, Heinecke A, Gobel U, et al: Evaluation of prognostic factors in a tumor volume-adapted treatment strategy for localized Ewing sarcoma of bone: the CESS 86 experience. Cooperative Ewing Sarcoma Study. Med Pediatr Oncol 1999, 32:186-195.

11. Ginsberg JP, de Alava E, Ladanyi M, Wexler LH, Kovar H, Paulussen M, Zoubek A, Dockhorn-Dworniczak B, Juergens H, Wunder JS, et al: EWS-FLI1 and EWS-ERG gene fusions are associated with similar clinical phenotypes in Ewing's sarcoma. Journal of clinical oncology: official journal of the American Society of Clinical Oncology 1999, 17:1809-1814.

12. Givens SS, Woo SY, Huang LY, Rich TA, Maor MH, Cangir A, Murray JA, Oswald MJ, Peters $L$, Jaffe N: Non-metastatic Ewing's sarcoma: twenty years of experience suggests that surgery is a prime factor for successful multimodality therapy. International journal of oncology 1999, 14:1039-1043.

13. Bacci G, Ferrari S, Bertoni F, Rimondini S, Longhi A, Bacchini P, Forni C, Manfrini M, Donati D, Picci P: Prognostic factors in nonmetastatic Ewing's sarcoma of bone treated with adjuvant chemotherapy: analysis of 359 patients at the Istituto Ortopedico Rizzoli. Journal of clinical oncology: official journal of the American Society of Clinical Oncology 2000, 18:4-11.

14. Jenkin RD, Al-Fawaz I, Al-Shabanah MO, Allam A, Ayas M, Memon M, Rifai S, Schultz HP: Metastatic Ewing sarcoma/PNET of bone at diagnosis: prognostic factors-a report from Saudi Arabia. Medical and pediatric oncology 2001, 37:383-389.

15. Krasin MJ, Davidoff AM, Rodriguez-Galindo C, Billups CA, Fuller CE, Neel MD, Merchant TE: Definitive surgery and multiagent systemic therapy for patients with localized Ewing sarcoma family of tumors: local outcome and prognostic factors. Cancer 2005, 104:367-373.

16. Bacci G, Longhi A, Ferrari S, Mercuri M, Versari M, Bertoni F: Prognostic factors in non-metastatic Ewing's sarcoma tumor of bone: an analysis of 579 patients treated at a single institution with adjuvant or neoadjuvant chemotherapy between 1972 and 1998. Acta oncologica 2006, 45:469-475.

17. De Angulo G, Hernandez M, Morales-Arias J, Herzog CE, Anderson P, Wolff J, Kleinerman ES: Early lymphocyte recovery as a prognostic indicator for high-risk Ewing sarcoma. Journal of pediatric hematology/ oncology 2007, 29:48-52.

18. Leavey PJ, Mascarenhas L, Marina N, Chen Z, Krailo M, Miser J, Brown K, Tarbell N, Bernstein ML, Granowetter L, et al: Prognostic factors for patients with Ewing sarcoma (EWS) at first recurrence following multimodality therapy: A report from the Children's Oncology Group. Pediatric blood \& cancer 2008, 51:334-338.

19. Jawad MU, Cheung MC, Min ES, Schneiderbauer MM, Koniaris LG, Scully SP. Ewing sarcoma demonstrates racial disparities in incidence-related and sex-related differences in outcome: an analysis of 1631 cases from the SEER database, 1973-2005. Cancer 2009, 115:3526-3536.

20. Kikuta K, Tochigi N, Shimoda T, Yabe H, Morioka H, Toyama Y, Hosono A, Beppu Y, Kawai A, Hirohashi S, Kondo T: Nucleophosmin as a candidate prognostic biomarker of Ewing's sarcoma revealed by proteomics. Clinical cancer research: an official journal of the American Association for Cancer Research 2009, 15:2885-2894. 
21. Sari N, Togral G, Cetindag MF, Gungor BS, Ilhan IE: Treatment results of the Ewing sarcoma of bone and prognostic factors. Pediatric blood \& cancer 2010, 54:19-24.

22. Kawai A, Healey JH, Boland PJ, Lin PP, Huvos AG, Meyers PA: Prognostic factors for patients with sarcomas of the pelvic bones. Cancer 1998 82:851-859.

23. Ahmad R, Mayol BR, Davis M, Rougraff BT: Extraskeletal Ewing's sarcoma. Cancer 1999, 85:725-731.

24. Cotterill SJ, Ahrens S, Paulussen M, Jurgens HF, Voute PA, Gadner H, Craft AW: Prognostic factors in Ewing's tumor of bone: analysis of 975 patients from the European Intergroup Cooperative Ewing's Sarcoma Study Group. Journal of clinical oncology: official journal of the American Society of Clinical Oncology 2000, 18:3108-3114.

25. de Alava E, Antonescu CR, Panizo A, Leung D, Meyers PA, Huvos AG, PardoMindan FJ, Healey JH, Ladanyi M: Prognostic impact of P53 status in Ewing sarcoma. Cancer 2000, 89:783-792.

26. Oberlin O, Deley MC, Bui BN, Gentet JC, Philip T, Terrier P, Carrie C, Mechinaud F, Schmitt C, Babin-Boillettot A, Michon J: Prognostic factors in localized Ewing's tumours and peripheral neuroectodermal tumours: the third study of the French Society of Paediatric Oncology (EW88 study). British journal of cancer 2001, 85:1646-1654.

27. Rutkowski P, Kaminska J, Kowalska M, Ruka W, Steffen J: Cytokine and cytokine receptor serum levels in adult bone sarcoma patients: correlations with local tumor extent and prognosis. Journal of surgical oncology 2003, 84:151-159.

28. Krasin MJ, Rodriguez-Galindo C, Davidoff AM, Billups CA, Fuller CE, Neel MD, Kun LE, Merchant TE: Efficacy of combined surgery and irradiation for localized Ewings sarcoma family of tumors. Pediatric blood \& cancer 2004, 43:229-236.

29. Matsunobu T, Tanaka K, Matsumoto Y, Nakatani F, Sakimura R, Hanada M, Li X, Oda Y, Naruse I, Hoshino H, et al: The prognostic and therapeutic relevance of p27kip1 in Ewing's family tumors. Clinical cancer research: an official journal of the American Association for Cancer Research 2004, 10:1003-1012.

30. Aksnes LH, Hall KS, Folleraas G, Stenwig AE, Bjerkehagen B, Taksdal I, Winderen M, Bruland OS, Saeter G: Management of high-grade bone sarcomas over two decades: the Norwegian Radium Hospital experience. Acta oncologica 2006, 45:38-46.

31. Mikulic D, llic I, Cepulic M, Giljevic JS, Orlic D, Zupancic B, Fattorini I, Seiwerth S: Angiogenesis and Ewing sarcoma-relationship to pulmonary metastasis and survival. Journal of pediatric surgery 2006, 41:524-529.

32. Cheung IY, Feng Y, Danis K, Shukla N, Meyers P, Ladanyi M, Cheung NK: Novel markers of subclinical disease for Ewing family tumors from gene expression profiling. Clinical cancer research: an official journal of the American Association for Cancer Research 2007. 13:6978-6983.

33. Rodriguez-Galindo C, Navid F, Liu T, Billups CA, Rao BN, Krasin MJ: Prognostic factors for local and distant control in Ewing sarcoma family of tumors. Annals of oncology: official journal of the European Society for Medical Oncology/ESMO 2008, 19:814-820.

34. Yonemori K, Yamaguchi U, Kaneko M, Uno H, Takeuchi M, Ando M, Fujiwara Y, Hosono A, Makimoto A, Hasegawa T, et al: Prediction of response and prognostic factors for Ewing family of tumors in a low incidence population. Journal of cancer research and clinical oncology 2008, 134:389-395.

35. Lee J, Hoang BH, Ziogas A, Zell JA: Analysis of prognostic factors in Ewing sarcoma using a population-based cancer registry. Cancer 2010 116:1964-1973

36. Terrier $\mathrm{P}$, Henry-Amar M, Triche TJ, Horowitz ME, Terrier-Lacombe MJ, Miser JS, Kinsella TJ, Contesso G, Llombart-Bosch A: Is neuro-ectodermal differentiation of Ewing's sarcoma of bone associated with an unfavourable prognosis? European journal of cancer 1995, 31A:307-314

37. Terrier P, Llombart-Bosch A, Contesso G: Small round blue cell tumors in bone: prognostic factors correlated to Ewing's sarcoma and neuroectodermal tumors. Seminars in diagnostic pathology 1996, 13:250-257.

38. de Alava E, Kawai A, Healey JH, Fligman I, Meyers PA, Huvos AG, Gerald WL, Jhanwar SC, Argani P, Antonescu CR, et al: EWS-FLI1 fusion transcript structure is an independent determinant of prognosis in Ewing's sarcoma. Journal of clinical oncology: official journal of the American Society of Clinical Oncology 1998, 16:1248-1255.
39. Paulussen M, Ahrens S, Craft AW, Dunst J, Frohlich B, Jabar S, Rube C, Winkelmann W, Wissing S, Zoubek A, Jurgens H: Ewing's tumors with primary lung metastases: survival analysis of 114 (European Intergroup) Cooperative Ewing's Sarcoma Studies patients. Journal of clinical oncology: official journal of the American Society of Clinical Oncology 1998, 16:3044-3052.

40. Baldini EH, Demetri GD, Fletcher CD, Foran J, Marcus KC, Singer S: Adults with Ewing's sarcoma/primitive neuroectodermal tumor: adverse effect of older age and primary extraosseous disease on outcome. Annals of surgery 1999, 230:79-86.

41. Luksch R, Sampietro G, Collini P, Boracchi P, Massimino M, Lombardi F, Gandola L, Giardini R, Fossati-Bellani F, Migliorini L, et al: Prognostic value of clinicopathologic characteristics including neuroectodermal differentiation in osseous Ewing's sarcoma family of tumors in children. Tumori 1999, 85:101-107.

42. Wei $G$, Antonescu $C R$, de Alava $E$, Leung D, Huvos AG, Meyers PA Healey JH, Ladanyi M: Prognostic impact of INK4A deletion in Ewing sarcoma. Cancer 2000, 89:793-799.

43. Zielenska M, Zhang ZM, Ng K, Marrano P, Bayani J, Ramirez OC, Sorensen P, Thorner $P$, Greenberg M, Squire JA: Acquisition of secondary structural chromosomal changes in pediatric ewing sarcoma is a probable prognostic factor for tumor response and clinical outcome. Cancer 2001, 91:2156-2164.

44. Martin RC, Brennan MF: Adult soft tissue Ewing sarcoma or primitive neuroectodermal tumors: predictors of survival? Archives of surgery 2003, 138:281-285

45. Fuchs $B$, Inwards $C Y$, Janknecht $R$ : Vascular endothelial growth factor expression is up-regulated by EWS-ETS oncoproteins and Sp1 and may represent an independent predictor of survival in Ewing's sarcoma. Clinical cancer research: an official journal of the American Association for Cancer Research 2004, 10:1344-1353.

46. Weston CL, Douglas C, Craft AW, Lewis IJ, Machin D: Establishing longterm survival and cure in young patients with Ewing's sarcoma. British journal of cancer 2004, 91:225-232.

47. Kreuter M, Paulussen M, Boeckeler J, Gerss J, Buerger H, Liebscher C, Kessler $T$, Jurgens $H$, Berdel WE, Mesters RM: Clinical significance of Vascular Endothelial Growth Factor-A expression in Ewing's sarcoma. European journal of cancer 2006, 42:1904-1911.

48. La TH, Meyers PA, Wexler LH, Alektiar KM, Healey JH, Laquaglia MP, Boland PJ, Wolden SL: Radiation therapy for Ewing's sarcoma: results from Memorial Sloan-Kettering in the modern era. International journal of radiation oncology, biology, physics 2006, 64:544-550.

49. Delepine N, Delepine G, Cornille H, Voisin MC, Brun B, Desbois JC: Prognostic factors in patients with localized Ewing's sarcoma: the effect on survival of actual received drug dose intensity and of histologic response to induction therapy. Journal of chemotherapy 1997, 9:352-363.

50. Picci P, Bohling T, Bacci G, Ferrari S, Sangiorgi L, Mercuri M, Ruggieri P, Manfrini M, Ferraro A, Casadei R, et al: Chemotherapy-induced tumor necrosis as a prognostic factor in localized Ewing's sarcoma of the extremities. Journal of clinical oncology: official journal of the American Society of Clinical Oncology 1997, 15:1553-1559

51. Abudu A, Davies AM, Pynsent PB, Mangham DC, Tillman RM, Carter SR, Grimer RJ: Tumour volume as a predictor of necrosis after chemotherapy in Ewing's sarcoma. The Journal of bone and joint surgery British volume 1999, 81:317-322.

52. Ohali A, Avigad S, Cohen IJ, Meller I, Kollender Y, Issakov J, Gelernter I, Goshen Y, Yaniv I, Zaizov R: Association between telomerase activity and outcome in patients with nonmetastatic Ewing family of tumors. Journal of clinical oncology: official journal of the American Society of Clinical Oncology 2003, 21:3836-3843.

53. Scotlandi K, Manara MC, Hattinger CM, Benini S, Perdichizzi S, Pasello M, Bacci G, Zanella L, Bertoni F, Picci P, Serra M: Prognostic and therapeutic relevance of HER2 expression in osteosarcoma and Ewing's sarcoma. European journal of cancer 2005, 41:1349-1361.

54. Avigad S, Naumov I, Ohali A, Jeison M, Berco GH, Mardoukh J, Stark B, Ash S, Cohen IJ, Meller I, et al: Short telomeres: a novel potential predictor of relapse in Ewing sarcoma. Clinical cancer research: an official journal of the American Association for Cancer Research 2007, 13:5777-5783.

55. Meynet O, Scotlandi K, Pradelli E, Manara MC, Colombo MP, SchmidAntomarchi H, Picci P, Bernard A, Bernard G: Xg expression in Ewing's 
sarcoma is of prognostic value and contributes to tumor invasiveness. Cancer research 2010, 70:3730-3738.

56. Sollazzo MR, Benassi MS, Magagnoli G, Gamberi G, Molendini L, Ragazzini P, Merli M, Ferrari C, Balladelli A, Picci P: Increased c-myc oncogene expression in Ewing's sarcoma: correlation with Ki67 proliferation index. Tumori 1999, 85:167-173.

57. Abudu A, Mangham DC, Reynolds GM, Pynsent PB, Tillman RM, Carter SR, Grimer RJ: Overexpression of p53 protein in primary Ewing's sarcoma of bone: relationship to tumour stage, response and prognosis. British journal of cancer 1999, 79:1185-1189.

58. Huang HY, Illei PB, Zhao Z, Mazumdar M, Huvos AG, Healey JH, Wexler LH, Gorlick R, Meyers P, Ladanyi M: Ewing sarcomas with p53 mutation or p16/p14ARF homozygous deletion: a highly lethal subset associated with poor chemoresponse. Journal of clinical oncology: official journal of the American Society of Clinical Oncology 2005, 23:548-558.

59. Maitra A, Roberts H, Weinberg AG, Geradts J: Aberrant expression of tumor suppressor proteins in the Ewing family of tumors. Archives of pathology \& laboratory medicine 2001, 125:1207-1212.

60. Ohali A, Avigad S, Zaizov R, Ophir R, Horn-Saban S, Cohen IJ, Meller I, Kollender Y, Issakov J, Yaniv I: Prediction of high risk Ewing's sarcoma by gene expression profiling. Oncogene 2004, 23:8997-9006.

61. Martins AS, Ordonez JL, Garcia-Sanchez A, Herrero D, Sevillano V, Osuna D, Mackintosh C, Caballero G, Otero AP, Poremba C, et al: A pivotal role for heat shock protein 90 in Ewing sarcoma resistance to anti-insulin-like growth factor 1 receptor treatment: in vitro and in vivo study. Cancer research 2008, 68:6260-6270.

62. Zanini C, Pulera F, Carta F, Giribaldi G, Mandili G, Maule MM, Forni M, Turrini F: Proteomic identification of heat shock protein 27 as a differentiation and prognostic marker in neuroblastoma but not in Ewing's sarcoma. Virchows Archiv: an international journal of pathology 2008, 452:157-167.

63. Hattinger CM, Potschger U, Tarkkanen M, Squire J, Zielenska M, KiuruKuhlefelt S, Kager L, Thorner P, Knuutila S, Niggli FK, et al: Prognostic impact of chromosomal aberrations in Ewing tumours. British journal of cancer 2002, 86:1763-1769.

64. Lopez-Guerrero JA, Pellin A, Noguera R, Carda C, Llombart-Bosch A: Molecular analysis of the 9p21 locus and p53 genes in Ewing family tumors. Laboratory investigation; a journal of technical methods and pathology 2001, 81:803-814

65. Hattinger CM, Rumpler S, Strehl S, Ambros IM, Zoubek A, Potschger U, Gadner H, Ambros PF: Prognostic impact of deletions at 1 p36 and numerical aberrations in Ewing tumors. Genes, chromosomes \& cancer 1999, 24:243-254.

66. Berghuis D, de Hooge AS, Santos SJ, Horst D, Wiertz EJ, van Eggermond MC, van den Elsen PJ, Taminiau AH, Ottaviano L, Schaefer KL, et al: Reduced human leukocyte antigen expression in advanced-stage Ewing sarcoma: implications for immune recognition. The Journal of pathology 2009, 218:222-231.

67. Holzer G, Obermair A, Koschat M, Preyer O, Kotz R, Trieb K: Concentration of vascular endothelial growth factor (VEGF) in the serum of patients with malignant bone tumors. Medical and pediatric oncology 2001, 36:601-604.

68. Pavlakovic H, Von Schutz V, Rossler J, Koscielniak E, Havers W, Schweigerer $L$ : Quantification of angiogenesis stimulators in children with solid malignancies. International journal of cancer Journal international du cancer 2001, 92:756-760.

69. Jimeno A, Daw NC, Amador ML, Cusatis G, Kulesza P, Krailo M, Ingle AM, Blaney SM, Adamson P, Hidalgo M: Analysis of biologic surrogate markers from a Children's Oncology Group Phase I trial of gefitinib in pediatric patients with solid tumors. Pediatric blood \& cancer 2007, 49:352-357.

70. Yabe H, Tsukahara T, Kawaguchi S, Wada T, Sato N, Morioka H: Overexpression of papillomavirus binding factor in Ewing's sarcoma family of tumors conferring poor prognosis. Oncology reports 2008, 19:129-134.

71. Bacci G, Ferrari S, Longhi A, Rimondini S, Versari M, Zanone A, Forni C Prognostic significance of serum LDH in Ewing's sarcoma of bone. Oncology reports 1999, 6:807-811.

doi:10.1186/2045-3329-2-7

Cite this article as: van Maldegem et al:: The clinical use of biomarkers as prognostic factors in Ewing sarcoma. Clinical Sarcoma Research 2012 2:7.

\section{Submit your next manuscript to BioMed Central and take full advantage of:}

- Convenient online submission

- Thorough peer review

- No space constraints or color figure charges

- Immediate publication on acceptance

- Inclusion in PubMed, CAS, Scopus and Google Scholar

- Research which is freely available for redistribution

Submit your manuscript at www.biomedcentral.com/submit
Biomed Central 